\title{
Primary Bone Non-Hodgkin Lymphoma of the Cervical Spine: Case Report and Review
}

\author{
Servikal Omurganun Primer Kemik Non-Hodgkin Lenfomasi: \\ Olgu Sunumu ve Derleme
}

\author{
Jose UNDABEITIA ${ }^{1}$, Roberto NOBOA ${ }^{1}$, Marc BOIX$^{2}$, Tomás GARCIA ${ }^{3}$, Maria Jose PANADÉS ${ }^{4}$, Pere NOGUÉS ${ }^{1}$ \\ ${ }_{1}^{1}$ Arnau de Vilanova University Hospital, Department of Neurosurgery, Lleida, Spain \\ ${ }^{2}$ Arnau de Vilanova University Hospital, Department of Neurology, Lleida, Spain \\ ${ }^{3}$ Arnau de Vilanova University Hospital, Department of Hematology, Lleida, Spain \\ ${ }^{4}$ Arnau de Vilanova University Hospital, Department of Pathology, Lleida, Spain
}

Corresponding Author: Jose UNDABEITIA / E-mail: joseundabeitia@hotmail.com

\begin{abstract}
Primary bone lymphomas (PBL) account for approximately $3 \%$ of all malignant tumors and are commonly found in the femur or pelvis. Only $1.7 \%$ of the PBLs are found in the spine. We report the case of a 73-year-old male complaining of cervical pain with progressive loss of strength and frequent falls. The MRI showed invasion of the fourth cervical vertebra and an infiltrating prevertebral mass. A C4 corpectomy was performed. The pathology exam revealed a diffuse large B-cell lymphoma. Due to the previous condition of the patient only radiotherapy treatment was applied. PBL arising from the cervical spine is an exceptional event. The low incidence of this condition and its unspecific radiological features make the diagnosis challenging for the clinician. When neurological deficit appears, early surgery for decompression is indicated, followed by local radiotherapy and systemic chemotherapy.
\end{abstract}

KEYWORDS: Non Hodgkin lymphoma, Cervical vertebrae, Diffuse large B-cell lymphoma

öz

Primer kemik lenfomaları (PKL) tüm malign tümörlerin yaklaşık \%3'ünü oluşturur ve sıklıkla femur veya pelviste bulunur. PKL'lerin sadece $\% 1,7$ 'si omurgada bulunur. Servikal ağrı, giderek azalan güç ve sık düşmelerden yakınan 73 yaşında bir erkek olguyu sunuyoruz. MRG dördüncü servikal vertebra invazyonu ve bir infiltratif prevertebral kitle gösterdi. C4 korpektomi yapıldı. Patoloji incelemesi difüz büyük B hücreli lenfoma olarak rapor edildi. Hastanın önceki durumu nedeniyle sadece radyoterapi tedavisi uygulandı. Servikal omurgadan köken alan PKL çok nadirdir. Bu hastalığın insidansının düşüklüğü ve spesifik olmayan radyolojik özellikleri tanıyı klinisyen için zor hale getirir. Nörolojik defisit belirdiğinde, dekompresyon için erken cerrahi endikedir ve sonrasında lokal radyoterapi ve sistemik kemoterapi uygulanır.

ANAHTAR SÖZCÜKLER: Non Hodgkin lenfoma, Servikal vertebra, Diffüz büyük B hücreli lenfoma

\section{INTRODUCTION}

While bone involvement is a common complication in advanced stage lymphomas, primary bone lymphoma $(\mathrm{PBL})$ is a rare disease, accounting for approximately $3 \%$ of malignant bone tumours, less than $2 \%$ of all lymphomas and less than $5 \%$ of extranodal lymphomas in adults $(3,5,7,12$, $16,19,21)$. The most common locations for PBL are reported to be the femur or the pelvis (50\%) and the long bones of the upper limbs (20\%) with the remaining $30 \%$ occurring in other locations such as the ribs, mandible or scapula $(14,16)$. A primary vertebral location accounts only for $1.7 \%$ of all PBLs (1), usually at the thoracic or lumbar levels, while a cervical location remains an exceptional event (23).

\section{CASE REPORT}

We report the case of a 73-year-old male who complained of a three month history of cervical pain and stiffness with progressive loss of strength in superior and inferior extremities causing frequent falls.

His past medical history included hypertensive cardiomyopathy and auricular fibrillation treated with diuretics and antiaggregation. His past surgical history included a transurethral prostatectomy due to a benign prostatic hyperplasia six years before that did not require posterior chemo or radiotherapy, with normal Prostate-Specific Antigen values $(\approx 1.61 \mathrm{ng} / \mathrm{ml})$ and non pathological echographies through the follow up.

On clinical examination, weakness of proximal upper limbs (3/5 Medical Research Council Scale [MRCS]) and of lower limbs (4/5 MRCS on all examined muscles) was observed. Hypoesthesia was also found, restricted to C4 and C5 dermatomes. There was no evidence of bladder or bowel dysfunction. Muscular tone was normal. Bilateral bicipital hyporeflexia was observed, with preserved tricipital reflex. Plantar reflex response was flexor bilaterally. 
Initially, cervical X-rays were obtained, which showed cervical kyphosis (Figure 1A). Laboratory evaluation on admission was unremarkable.

Due to this findings a cervical MRI was obtained, which disclosed a tumoural invasion of the fourth cervical vertebra, and an infiltrating prevertebral mass spreading from C3 to C5, occupying the intervertebral foramina and invading the anterior epidural space causing marked spinal cord compression (Figure 1B-E).

Elective surgery was then indicated due to the antiaggregation status of the patient, performing an anterior cervical approach for a C4 corpectomy. Microsurgical excision of the prevertebral and epidural mass was achieved. A titanium mesh and a screwed plate were used for fixation (Figure 1F,G).

The procedure was uneventful and our patient was discharged on the seventh postoperative day, showing improvement on both upper and lower limb deficits, with mild weakness remaining on proximal upper extremities (4/5 MRCS). No complications appeared. The pathology exam revealed a diffuse large B-cell lymphoma (Figure $2 \mathrm{~A}-\mathrm{C}$ ).

No evidence of lymphadenopathy or other mass lesions were found on physical examination. Magnetic resonance imaging (MRI) of the brain was also negative. A staging examination including computed tomography (CT) and positron emission tomography (PET) of thorax and abdomen showed no additional suspicious sites. According to the clinical manifestation and pathological results, the diagnosis was established to be stage IE (Involvement of a single extralymphatic organ or site in the Ann Arbor Staging System) diffuse large B-cell lymphoma.

Chemotherapy treatment was considered, but was not applied due to the age and comorbidities of our patient.
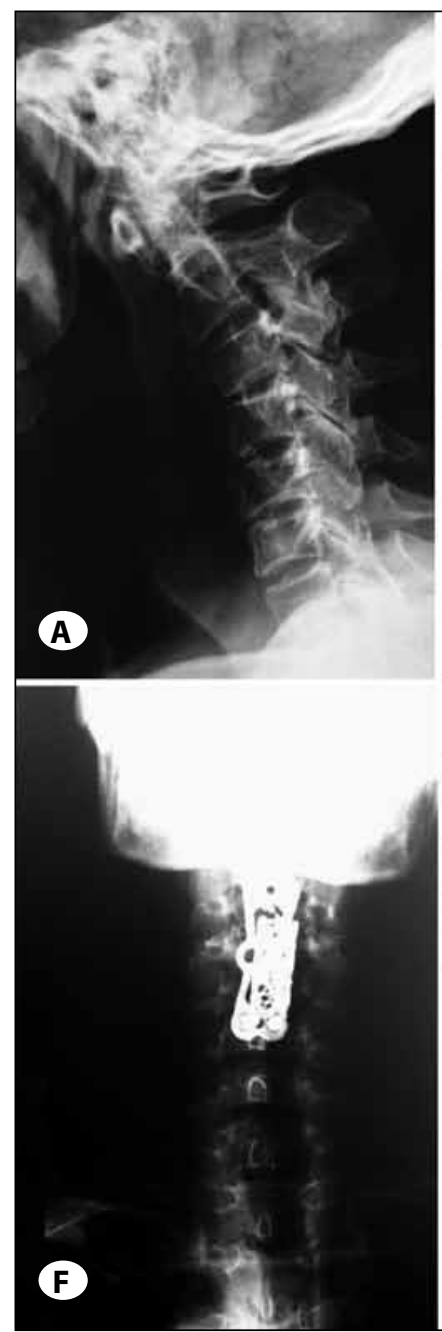
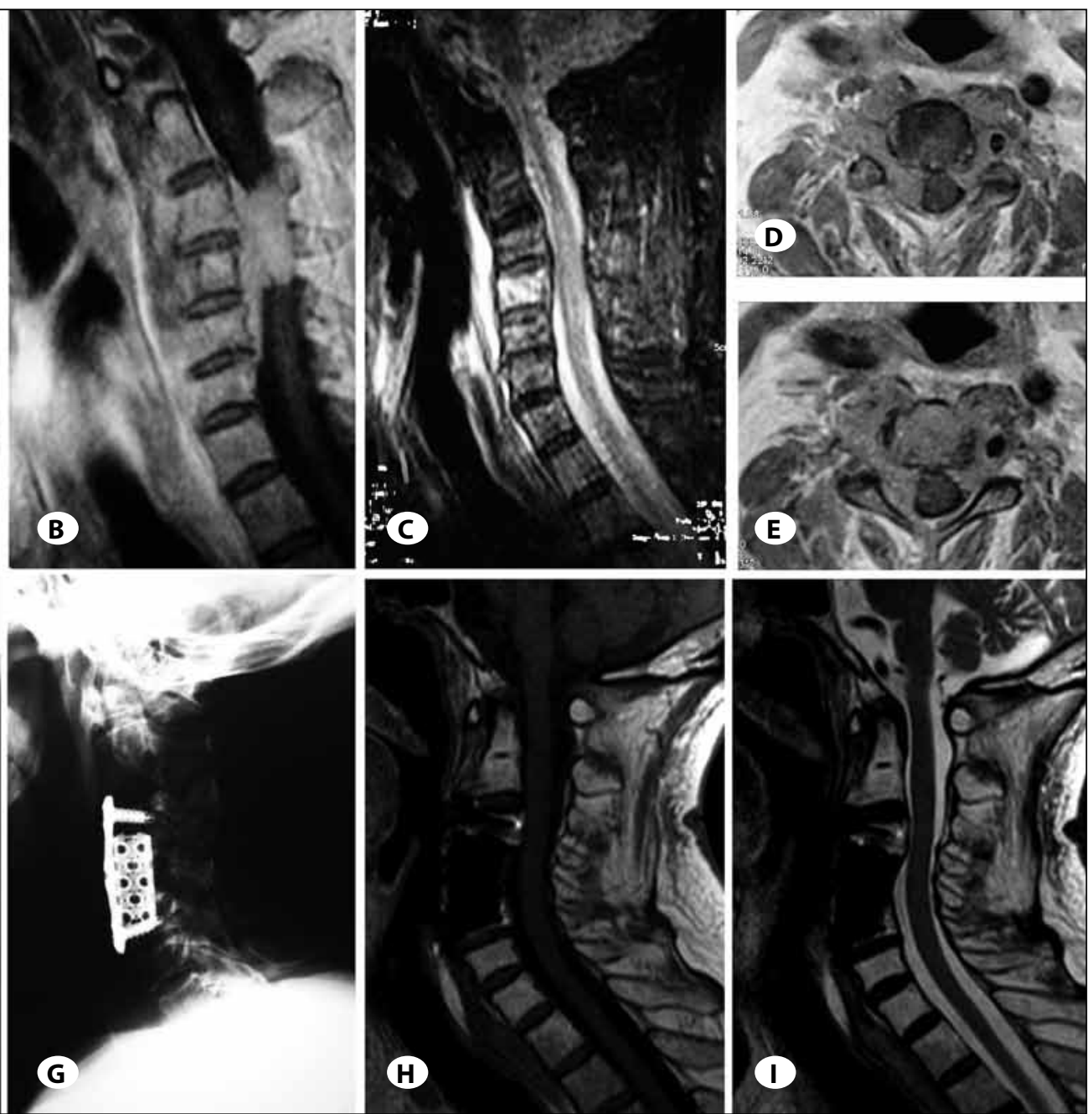

Figure 1: A) Lateral cervical X-ray showing kyphosis. B) T1 weighted, gadolinium enhanced sagittal MRI showing a prevertebral mass spreading from C3-C5. C) T2 weighted sagittal MRI showing C4 hyperintensity. D,E) T1 weighted, gadolinium enhanced axial MRI, showing invasion of the fourth vertebral vertebra, the anterior epidural space and bilateral foramina. F,G) Anterior-posterior and lateral cervical X-ray showing a C4 corpectomy with titanium mesh and C3-C5 screwed plate and improved cervical alignment. H, I) T1 and 22 weighted cervical sagittal MRI showing the same findings and decompression of the spinal canal. 

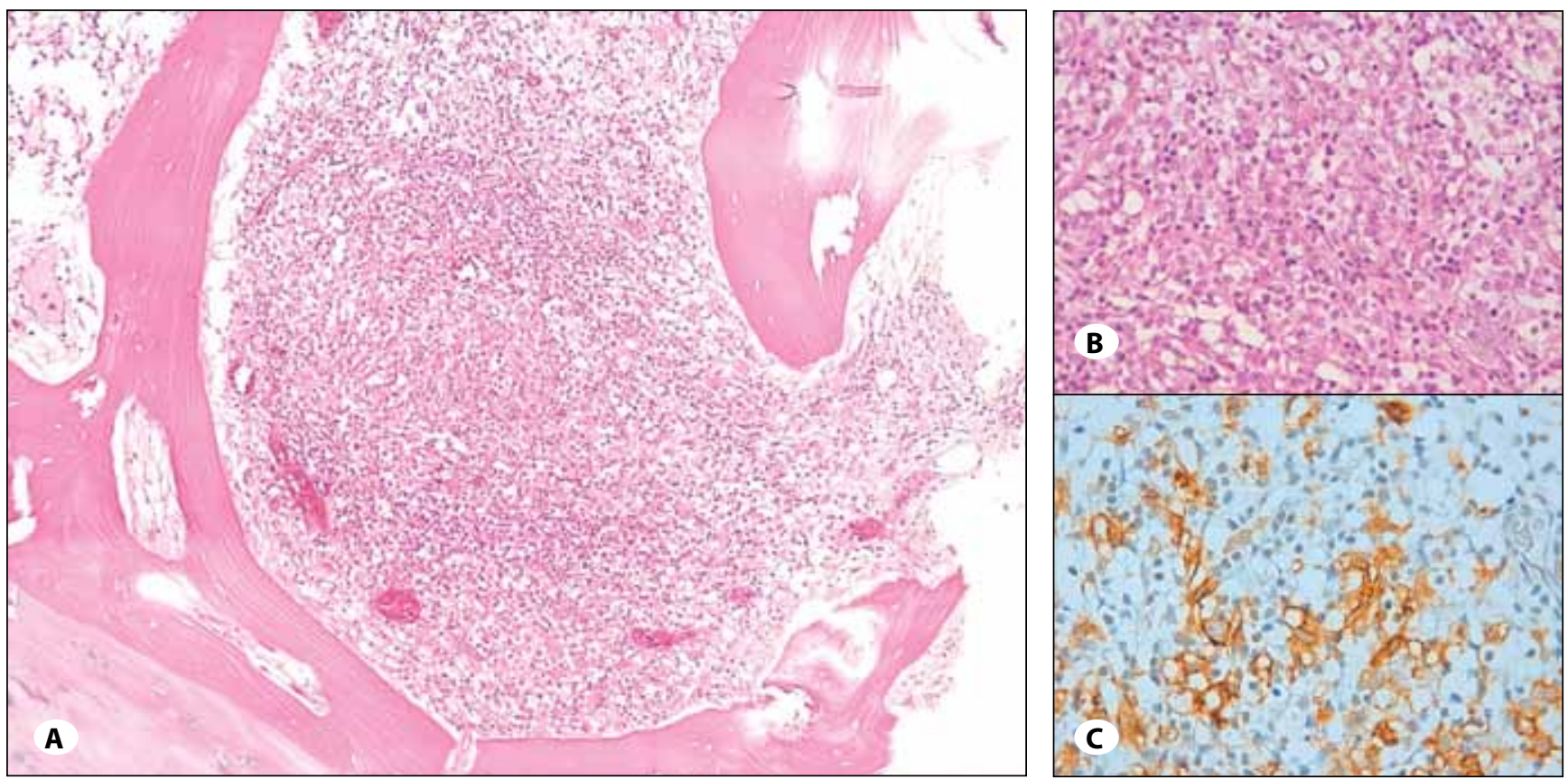

Figure 2: A) Hematoxylin-Eosin (H/E) 10x preparation showing bone infiltration by atypical cells in clusters pattern. B) H/E 40x preparation with atypical cells with large nuclei and prominent nucleoli. C) Immunohistochemistry showing positive CD 20 in $40 x$ magnification.

Radiotherapy treatment was applied six weeks after the surgical procedure, administrating a total dose of $40 \mathrm{~Gy}$ in 20 sessions, 2 Gy each, over a four week period.

On follow up, the patient completely recovered from his previous symptoms with no motor deficit remaining after six months of physical rehabilitation treatment. On the last PET scan, 26 months after surgery, no sign of active disease was found. The last MRI, performed 36 months after surgery, did not show local recurrence (Figure $1 \mathrm{H}, \mathrm{I}$ ).

\section{DISCUSSION}

PBL was first defined as a distinct clinicopathological entity in 1939 by Parker and Jackson, who originally named it as "Primary reticulum cell sarcoma of bone" (17). It was later, in 1950, when Coley et al. (6) suggested that PBL should be defined as 'lymphoma presenting in an osseous site with no evidence of disease elsewhere for at least six months after diagnosis'. In the World Health Organization classification of neoplasms of the hematopoietic and lymphoid tissues, published in 2001 and updated in 2008, PBL is defined and characterized as an independent disease (4). The most common histological type of PBL is the diffuse large-B-cell lymphoma which accounts for approximately the $90 \%$ of the cases, as ours, and it is characterized by pan- $B, \operatorname{lgS}+, C D$ $5-/+$ (positive in up to $10 \%$ of the cases), CD10-/+ (positive in between 30 to $60 \%$ of the cases) and CD 30+/- (most commonly positive in anaplastic type) immunophenotype (2, 7, 15, 20-22).

The generally acknowledged criteria for the diagnosis of PBL are: 1. Primary involvement site of the bone, 2. No evidence of extra-bone lesion according to the clinical and radiographic examination, 3 . No evidence of any other extrabone lesion 6 months after bone lesion is diagnosed, 4. The diagnosis is confirmed by both pathological morphology and immunohistochemistry (24).

PBL is slightly more frequent in male, with a median age at diagnosis ranging from mid-40s to mid-60s with an incidence peak at 50 years, although the age range is wide $(1,9,12,14$, 25). There has been an increase in the incidence of this disease, due to the increasing number of immunosuppressed patients and the ageing of the population (5). Published series slightly differ in the most common location for PBL but, although any bone can be involved, the most reported sites are femur and pelvis, followed by other long bones in upper extremities (3, $5-7,12,25)$. Primary vertebral location is very uncommon, usually arising from the thoracic and lumbar spine $(2,5,8,23)$.

The most frequent presentation of $\mathrm{PBL}$ is bone pain or a palpable mass or both $(3,7,12)$. When the spine bones are involved back pain is the most common symptom. Neurological findings may include decreased sensory levels, hyperreflexia, paraparesis or paraplegia and bowel or bladder dysfunction $(2,9,23)$. Spinal cord compression has been reported to appear as the first manifestation, but usually back pain tends to precede the onset of myelopathy by $a$ variable period of time $(1,18,20)$. Ramadan (21) reported an incidence of $50 \%$ of spinal cord compression in patients with PBL vertebral involvement. Systemic " $B$ " symptoms, such as unexplained fever, night sweat or unexplained weight loss exceeding $10 \%$ of body weight six months prior to diagnosis might be present, but are relatively uncommon $(7,12)$. 
The diagnostic study should begin with simple X-ray. There is not a specific pattern for this lesion and studies can eventually be normal. When present, the most common pattern is destructive osteolytic lesion that may be observed arising from the medulla, with "moth-eaten" appearance or, occasionally, as a focal lytic lesion with well-defined margin. Other findings such as cortical disruption, pathological fractures or soft tissue masses, can also be present but are difficult to detect with this technique $(7,9,12,14,16,23$, 25). Differential diagnosis should be made at this point with metastatic disease of the affected bone $(5,11)$. Difficulty in identifying such lesions may result in delayed diagnosis of the process $(10,19)$.

MRI is the imaging technique of choice when PBL is suspected due to its noninvasive nature and greater anatomic detail. Typically, areas of bone marrow replacement can be observed, appearing as hypointense on T1-weighted sequences and hyperintense on T2-weighted sequences. Short TI Inversion Recovery (STIR) can also detect the abnormality in the bone marrow. MRI is also particularly useful in evaluating the soft tissue extension and for the assessment of spine involvement $(9,10,12,14,18,19,25)$.

After the neuroimaging study is complete, the differential diagnosis should include entities such as lymphoma, plasmacytoma, metastases, myeloma and osteomyelitis, which are usually associated with destruction of the bone (2, $14,16)$. Once the diagnosis of diffuse large-B-cell lymphoma is established, polyostotic, metastatic or regional lymphatic disease involvement should be discarded (11). PET scan is a powerful imaging technique that can be of great help for the accurate localization and staging of $\mathrm{PBL}(12,13)$.

When neurological deficit is present, early surgical decompression is mandatory and stabilization may also be required to avoid irreversible damage, preserve the function and maintain quality of life $(18,23)$. Management of this disease has undergone significant evolution since the 1960s when local radiotherapy alone was established as a standard of care for PBL, resulting in good control rates of the local lesion but relatively high rates of systemic failure $(3,7)$. Since then, several chemotherapy regimens have been used until the rituximab, cyclophosphamide, doxorubicin, vincristine, and prednisone (RCHOP) was introduced in 2001. At present, standard treatment is based on systemic chemotherapy and local radiotherapy $(11,18,20,21,25)$. The overall outcome of PBL is usually good with a 5 year survival ranging from $62 \%$ to $88 \%(3,12,21,25)$.

\section{CONCLUSION}

Primary bone lymphomas arising from the cervical spine are an exceptional event. Diagnosis of this condition may be challenging due to its low incidence and unspecific radiological features. When neurological impairment occurs, early surgery for decompression is indicated, followed by local radiotherapy and systemic chemotherapy.

\section{REFERENCES}

1. Ahmadi SA, Frank S, Hanggi D, Eicker SO: Primary spinal marginal zone lymphoma - case report and review of the literature. Neurosurgery 71:E495-508, 2012

2. Barnard M, Perez-Ordonez B, Rowed DW, Ang LC: Primary spinal epidural mantle cell lymphoma: Case report. Neurosurgery 47:1239-1241, 2000

3. Beal K, Allen L, Yahalom J: Primary bone lymphoma: Treatment results and prognostic factors with long-term follow-up of 82 patients. Cancer 106:2652-2656, 2006

4. Campo E, Swerdlow SH, Harris NL, Pileri S, Stein H, Jaffe ES: The 2008 WHO classification of lymphoid neoplasms and beyond: Evolving concepts and practical applications. Blood 117:5019-5032, 2011

5. Castro-Bouzas D, Prieto-Gonzalez A, Serramito-Garcia $R$, Santin-Amo JM, Reyes-Santias RM, Allut AG, GelabertGonzalez M: Primary cranial vault lymphoma. Rev Neurol 53:735-738, 2011

6. Coley BL, Higinbotham NL, Groesbeck HP: Primary reticulumcell sarcoma of bone; summary of 37 cases. Radiology 55: 641-658, 1950

7. Dubey P, Ha CS, Besa PC, Fuller L, Cabanillas F, Murray J, Hess MA, Cox JD: Localized primary malignant lymphoma of bone. Int J Radiat Oncol Biol Phys 37:1087-1093, 1997

8. Haddad $P$, Thaell JF, Kiely JM, Harrison EG, Miller RH: Lymphoma of the spinal extradural space. Cancer 38: 1862-1866, 1976

9. Ho L, Valenzuela D, Negahban A, Wassef H: Primary spinal epidural non-Hodgkin lymphoma demonstrated by FDG PET/CT. Clin Nucl Med 35:487-489, 2010

10. Khalid I, Rival J, Salama ME, Banghar PK, Janakiraman N: Unusual presentations of hematologic malignancies: Case 2. Precursor B-cell lymphoblastic lymphoma presenting as spinal cord compression. J Clin Oncol 22:1331-1333, 2004

11. Mendenhall NP, Jones JJ, Kramer BS, Hudson TM, Carter RL, Enneking WF, Marcus RB, Jr Million RR: The management of primary lymphoma of bone. Radiother Oncol 9:137-145, 1987

12. Mikhaeel NG: Primary bone lymphoma. Clin Oncol 24: 366-370, 2012

13. Moog F, Kotzerke J, Reske SN: FDG PET can replace bone scintigraphy in primary staging of malignant lymphoma. J Nucl Med 40:1407-1413, 1999

14. Mulligan ME, McRae GA, Murphey MD: Imaging features of primary lymphoma of bone. Am J Roentgenol 173: 1691 1697, 1999

15. Omuro AM, Abrey LE: Chemotherapy for primary central nervous system lymphoma. Neurosurgical Focus 21:E12, 2006

16. Parekh HC, Sharma RR, Keogh AJ, Prabhu SS: Primary malignant non-Hodgkin's lymphoma of cranial vault: A case report. Surg Neurol 39:286-289, 1993

17. Parker F, Jackson H: Primary reticulum cell sarcoma of bone. Surg Gynecol Obstet 68:45-53, 1939 
18. Perez-Martinez DA, Saiz-Diaz RA, de Toledo $M$, Berbel A, Martinez-Salio A, Prieto S: Cervical radiculopathy as a form of presentation of non-Hodgkin's lymphoma. Rev Neurol 27: 91-93, 1998

19. Pérez Camarero D, Martí-Cabané J, Caso J, López A, Antón E: Linfoma vertebral primitivo. Rev Neurol 32:96-100, 2001

20. Perry JR, Deodhare SS, Bilbao JM, Murray D, Muller P: The significance of spinal cord compression as the initial manifestation of lymphoma. Neurosurgery 32:157-162, 1993

21. Ramadan KM, Shenkier T, Sehn LH, Gascoyne RD, Connors JM: A clinicopathological retrospective study of 131 patients with primary bone lymphoma: A population-based study of successively treated cohorts from the British Columbia Cancer Agency. Ann Oncol 18:129-135, 2007
22. Rozman C: Non-Hodgkin's lymphomas: Current aspects. Rev Neurol 31:1275-1280, 2000

23. Smith ZA, Sedrak MF, Khoo LT: Primary bony non-Hodgkin lymphoma of the cervical spine: A case report. J Med Case Rep 4:35, 2010

24. Unni KK, Hogendoom P: World health organization classification of tumours pathology and genetics of tumours of soft tissue and bone. Lyon: ARC Press, 2002

25. Zhang X, Chang CK, Song LX, Xu L, Wu LY, Li X: Primary lymphoma of bone: $A$ case report and review of the literature. Med Oncol 28:202-206, 2011 